ENTREPRENEURSHIP AND SUSTAINABILITY ISSUES

ISSN 2345-0282 (online) http://jssidoi.org/jesi/

2019 Volume 6 Number 4 (June)

http://doi.org/10.9770/jesi.2019.6.4(24)

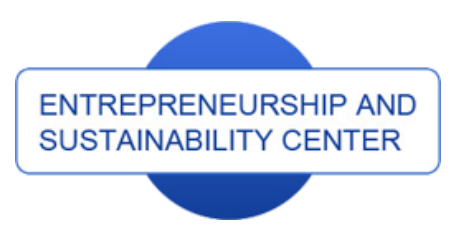

Publisher

http://jssidoi.org/esc/home

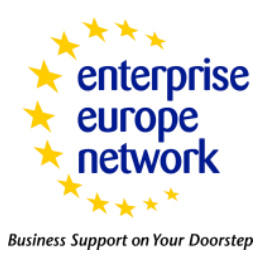

CASPA

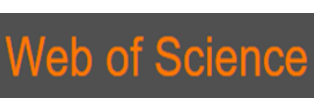

1) Clarivate

\title{
A MODEL FOR MANAGING THE INNOVATION-DRIVEN DEVELOPMENT OF A REGIONAL INDUSTRIAL COMPLEX
}

\author{
Valery Vasilyevich Bezpalov ${ }^{1}$, Dmitry Valerievich Fedyunin² ${ }^{2}$, Natalya Anatolievna Solopova ${ }^{3}$, Svetlana \\ Alekseevna Avtonomova ${ }^{4}$, Sergey Alexandrovich Lochan ${ }^{5}$ \\ ${ }_{1,24,5}$ Russian Economic University named after GV Plekhanov, Moscow, Russia \\ ${ }^{3}$ Moscow State (National Research) University of Civil Engineering, Moscow, Russia
}

E-mails: ${ }^{1}$ valerib1@yandex.ru ; ${ }^{2}$ fedunine@mail.ru ; ${ }^{3}$ ushanovan@mail.ru ; ${ }^{4}$ avtonomoval@yandex.ru, ${ }^{5}$ lochansa@mail.ru

Received 16 February 2019; accepted 15 April 2019; published 30 June 2019

\begin{abstract}
A key structural issue in the innovation-driven development of Russia's regional industrial complexes (RIC) to face over the next 5-10 years is "filling", in the context of the contribution of industrial production to GDP, the niche currently occupied by the resource and raw materials sector of the national economy (in particular, enterprises within the fuel-and-energy complex). This issue of filling the gaps in GDP is quite complex and requires considerable resources and significant statutory effort. Ideally, this process must involve galvanizing RIC's use of innovative technology, with a special strategic focus on creating high-tech industrial production operations. Since RICs are a key subject of the innovations market, it may be worth exploring the effect of the innovations market on these complexes, while also investigating their own self-development processes in the context of organizing and implementing innovation activity. It is also worth noting that the effect of the innovations market on RICs is manifested in all major segments within the innovations market: federal, sectoral, regional, corporate, and intra-firm.
\end{abstract}

Keywords: managing innovation-driven development; regional industrial complex; innovations market; innovative products; institutionalinnovation environment; management model

Reference to this page should be made as follows: Bezpalov, V.V.; Fedyunin, D.V.; Solopova, N.A.; Avtonomova, S.A.; Lochan, S.A. 2019. A model for managing the innovation-driven development of a regional industrial complex, Entrepreneurship and Sustainability Issues 6(4): 1884-1896. http://doi.org/10.9770/jesi.2019.6.4(24)

JEL Classification: $\mathrm{O} 3$

\section{Introduction}

An investigation of relevant trends in and laws governing the innovation-driven development of a regional industrial complex (RIC) helped establish that, given the keen use of innovations, it will be as many as 5-7 years before the innovation-driven development of these complexes results in high-tech production operations gaining a firm foothold and starting to help achieve high rates of GDP growth (as active and influential structural elements) - and that is provided that the timeframes for carrying into effect relevant plans for conducting innovation activity and interacting with participants in the innovations market are observed. Therefore, in the near future the 


\section{ENTREPRENEURSHIP AND SUSTAINABILITY ISSUES}

ISSN 2345-0282 (online) http://jssidoi.org/jesi/

2019 Volume 6 Number 4 (June)

http://doi.org/10.9770/jesi.2019.6.4(24)

innovation-driven development of RICs will predominantly be associated with the traditional raw materials sector and with the services sector. As a result, the process of new sectors taking over for the raw materials sector, as well as the development of the infrastructural segment of the national economy, will proceed at quite a slow pace, with a major breakthrough unlikely to be achieved soon in terms of galvanizing innovation activity and creating an adaptive innovation space in the national economy. Under these economic conditions, one of the most strategically effective and realistic ways is to consolidate small creative, innovation-focused enterprises around integrated establishments, which should involve the provision of statutory support for these concentration processes and proper coordination on the part of public authorities (Ignatavičius et al. 2015; Tvaronavičienė, Černevičiūtè, 2015; Valter et al. 2016; Tvaronavičienė, 2017; Razminienè, Tvaronavičienė 2017; Monni et al., 2017; Goncharenko et al., 2019; Petrenko et al., 2019).

Today's practice of providing support for innovation-driven development requires developing an adaptive model for managing innovation activity in RIC. The focus specifically ought to be on employing a sound adaptive system, as opposed to undertaking plain measures of traditional support for RICs, which have failed to result in the desired effectiveness and efficiency of investment in the creation of innovative products and services.

\section{Methods}

If it is changes taking place in the corporate segment of the innovations market that are taken as the basis for RIC's self-development, a key focus here must be on putting in place relevant standards designed to ensure the coordination of the interests of innovation-focused agents within the RIC (Aniskin et al. 2009). In this case, it may be easier to identify a set of rational procedures of innovation marketing and come up with proper tools for developing and implementing RIC's technological and investment policy, which should help forecast changes in the brand portfolio of enterprises within the complex.

As regards RIC's self-development by way of changes in the intra-firm segment of the innovations market, here it will help to put in place and make rational use of proper standards for effective activity by the divisions of business entities within the RIC in developing and implementing innovations. This may help identify principal sources of reserves for the support of the innovation-driven development of RIC, as well as help build a system of proper principles for making and implementing effective innovation-related decisions, which is highly crucial today for ensuring the rational operation of innovation infrastructure facilities within RICs.

With that said, rationalizing the use of and selecting a particular form of managing RIC's innovation-driven development in a climate of interaction with the innovations market is closely linked with developing relevant strategies and scenarios for the innovation-driven development of specific enterprises within the RIC and of the entire RIC as a whole.

Table 1. Methods for Managing RIC's Innovation-Driven Development Depending on Particular Segments within the Innovations Market

\begin{tabular}{|c|c|c|c|}
\hline $\begin{array}{l}\text { Segment/ } \\
\text { subsystem }\end{array}$ & \begin{tabular}{|c|} 
Method for managing \\
innovation-driven development
\end{tabular} & Input information for RIC & Output information from RIC \\
\hline Federal segment & $\begin{array}{c}\text { Administering strategic control } \\
\text { over the development of } \\
\text { situations in the 'innovations - } \\
\text { target markets' area }\end{array}$ & $\begin{array}{c}\text { Scientific-technical, technological, statistical, } \\
\text { and patent information, as well as hindsight } \\
\text { data }\end{array}$ & $\begin{array}{l}\text { Information related to the fine-tuning of } \\
\text { strategic priorities for innovation-driven } \\
\text { development }\end{array}$ \\
\hline $\begin{array}{l}\text { Sectoral } \\
\text { segment }\end{array}$ & \begin{tabular}{|} 
Developing a system of \\
effective management of \\
innovation projects; \\
coordination and control of the \\
formation and development of \\
a project portfolio
\end{tabular} & $\begin{array}{l}\text { Information on the availability of unique } \\
\text { resources required for the production of } \\
\text { innovative output }\end{array}$ & $\begin{array}{l}\text { Information on innovation projects } \\
\text { accepted for implementation; } \\
\text { information on the volume of and } \\
\text { timeframes for getting the resources }\end{array}$ \\
\hline
\end{tabular}


ENTREPRENEURSHIP AND SUSTAINABILITY ISSUES

ISSN 2345-0282 (online) http://jssidoi.org/jesi/

2019 Volume 6 Number 4 (June)

http://doi.org/10.9770/jesi.2019.6.4(24)

\begin{tabular}{|c|c|c|c|}
\hline $\begin{array}{l}\text { Segment/ } \\
\text { subsystem }\end{array}$ & \begin{tabular}{|c|} 
Method for managing \\
innovation-driven development
\end{tabular} & Input information for RIC & Output information from RIC \\
\hline $\begin{array}{c}\text { Regional } \\
\text { segment }\end{array}$ & $\begin{array}{l}\text { Selecting appropriate forms of } \\
\text { stimulating and providing } \\
\text { continual support for an active } \\
\text { strategy for innovation-driven } \\
\text { development }\end{array}$ & $\begin{array}{l}\text { Information on the trends in and prospects for } \\
\text { statutory and legislative regulation of } \\
\text { innovation activity in the economy }\end{array}$ & $\begin{array}{c}\text { Information on key partners to the RIC } \\
\text { in the context of innovation activity and } \\
\text { criteria for fostering rational cooperation } \\
\text { with them }\end{array}$ \\
\hline $\begin{array}{l}\text { Corporate } \\
\text { segment }\end{array}$ & $\begin{array}{c}\text { Conducting a set of activities } \\
\text { on creating within the RIC a } \\
\text { proper innovation management } \\
\text { climate }\end{array}$ & $\begin{array}{c}\text { Information from experts obtained in assessing } \\
\text { the trends in and prospects for organizing and } \\
\text { managing innovation activity in a socio- } \\
\text { economic system }\end{array}$ & $\begin{array}{c}\text { Information on the experience of } \\
\text { developing and implementing innovative } \\
\text { solutions and the choice of area for } \\
\text { developing and implementing } \\
\text { innovations factoring in the competence } \\
\text { level of RIC personnel }\end{array}$ \\
\hline $\begin{array}{c}\text { Intra-firm } \\
\text { segment }\end{array}$ & \begin{tabular}{|c|} 
Ensuring the maximum \\
decentralization of managerial \\
powers, whilst preserving the \\
integration relationships
\end{tabular} & $\begin{array}{c}\text { Information on the participants in innovation } \\
\text { activity and the potential for coordinating their } \\
\text { activity at the level of resource and } \\
\text { organizational support }\end{array}$ & $\begin{array}{l}\text { Information on the conditions of and } \\
\text { potential for the transfer of experience } \\
\text { and knowledge in the RIC for the } \\
\text { purpose of integrating all levels of } \\
\text { innovation management }\end{array}$ \\
\hline $\begin{array}{l}\text { Scientific- } \\
\text { methodological } \\
\text { subsystem }\end{array}$ & $\begin{array}{c}\text { Ensuring the RIC's appropriate } \\
\text { reaction to a number of } \\
\text { strategic issues }\end{array}$ & $\begin{array}{l}\text { Information on possible scenarios for the } \\
\text { development of various areas of technology } \\
\text { and science; information on potential } \\
\text { technological horizons }\end{array}$ & $\begin{array}{c}\text { Catalogues and datasheets for innovation } \\
\text { projects, products, and technologies } \\
\text { offered for implementation to investors } \\
\text { by the RIC }\end{array}$ \\
\hline $\begin{array}{l}\text { Innovation } \\
\text { subsystem }\end{array}$ & \begin{tabular}{|c|} 
Searching for new and \\
developing existing markets for \\
innovative products which are \\
within the strategic zones of the \\
RIC's responsibility
\end{tabular} & $\begin{array}{l}\text { Information on whether there are currently in } \\
\text { place functioning prototypes, special } \\
\text { authorization procedures, systems of } \\
\text { environmental regulations, and market barriers } \\
\text { (the degree to which it is possible to sell } \\
\text { various components or materials independently } \\
\text { factoring in the potential for those sales to be } \\
\text { blocked by competitors) }\end{array}$ & $\begin{array}{l}\text { Information on newly developed } \\
\text { innovative products within the RIC }\end{array}$ \\
\hline $\begin{array}{l}\text { Economic } \\
\text { subsystem }\end{array}$ & \begin{tabular}{|c|} 
Rational use of strategic \\
resources within the RIC; \\
rational exchange of resources
\end{tabular} & $\begin{array}{l}\text { Information on the structure of target markets; } \\
\text { RIC segments in them; levels of demand; } \\
\text { levels of supply; competitors; consumers; } \\
\text { competing goods; suppliers; general economic } \\
\text { trends; sectoral trends; risks inherent in the } \\
\text { development and implementation of } \\
\text { innovations }\end{array}$ & $\begin{array}{c}\text { Information on implemented market and } \\
\text { economic mechanisms for organizing } \\
\text { and managing innovation activity within } \\
\text { the RIC }\end{array}$ \\
\hline $\begin{array}{l}\text { Organizational- } \\
\text { managerial } \\
\text { subsystem }\end{array}$ & $\begin{array}{c}\text { Putting in place strategic sets of } \\
\text { structures acting as strategic } \\
\text { business processes }\end{array}$ & $\begin{array}{l}\text { Information on the commercial potential of } \\
\text { technological innovations and on tools for } \\
\text { promoting projects on commercializing } \\
\text { technologies within the RIC }\end{array}$ & $\begin{array}{l}\text { Information on assistance provided by } \\
\text { the RIC to small enterprises engaged in } \\
\text { the implementation of risky innovation } \\
\text { projects }\end{array}$ \\
\hline $\begin{array}{l}\text { Infrastructural } \\
\text { subsystem }\end{array}$ & \begin{tabular}{|} 
Developing and implementing \\
strategic plans on \\
infrastructural support for \\
innovation activity programs
\end{tabular} & $\begin{array}{l}\text { Information on entities operating in the area of } \\
\text { support for innovation and technological } \\
\text { activity within the RIC, including information } \\
\text { on sources of resource support for independent } \\
\text { infrastructural projects within the RIC (leasing) }\end{array}$ & $\begin{array}{l}\text { Information on quantitative and } \\
\text { qualitative indicators of the sufficiency } \\
\text { of infrastructural support for innovation } \\
\text { within the RIC }\end{array}$ \\
\hline
\end{tabular}

Source: elaborated by authors

Another major method for managing RIC's innovation-driven development is foresight, which is a key area of research activity by participants in innovation activity within the RIC. These issues must be explored in conjunction with issues related to the development and implementation of a program for the innovation-driven development of RIC.

\section{Results}

As at January 1, 2017, Russia ranked 43rd among 128 countries in the Global Innovation Index. To note, there was a 5-percentage point improvement relative to the same period of 2016. The top three spots in the Global 


\section{ENTREPRENEURSHIP AND SUSTAINABILITY ISSUES}

ISSN 2345-0282 (online) http://jssidoi.org/jesi/

2019 Volume 6 Number 4 (June)

http://doi.org/10.9770/jesi.2019.6.4(24)

Innovation Index were occupied at the time by Switzerland, Sweden, and Great Britain. Of interest is the fact that, compared with its performance as at January 1, 2014, Russia moved up the ranks in innovation input, however, its performance worsened in innovation output, with the nation's efficiency in the development and implementation of innovations having declined steadily over the years. In addition, the nation has failed to be among the world's top 100 nations in the following indicators: Innovation Linkages, Investment, State of Cluster Development, Regulatory Quality, and Political Stability.

In the Bloomberg Innovation Index, as at January 1, 2017, Russia was one of the 50 nations with the worst dynamics in terms of the development of innovation activity, ranking 26th versus 12th in 2016. However, it should be noted that Russia led the way in relative share of certified specialists, expenditure on innovation, and number of patents registered. In effect, while possessing sufficient scientific-technical potential, Russia appears to have failed to make efficient use thereof within the national and regional economies - in 2017 the nation ranked 24th in relative share of high-tech enterprises within its RICs, versus 8th in 2016.

As at January 1, 2017, the relative share of the output of science-driven and high-tech sectors relative to the nation's GDP was 22.3\% (Popkov \& Kotsiubinskii, 2017). It also should be noted that in Russia the approach to construing the term "science-driven and high-tech products" varies from institution to institution. For instance, the Ministry of Industry and Trade of the Russian Federation has yet to recognize as existing the sectors concerned with the manufacture of computers, electric equipment, and optical and electronic products. Having said that, materials by the above institution do address innovation activity in the area of design and manufacture of bicycles. Only the Russian Federal State Statistics Service appears to observe the commonly accepted international approach in terms of associating industrial output with its high-tech varieties.

As evidenced from Table 2, the Ministry of Industry and Trade of the Russian Federation considers the level of innovation activity in the country to be (two times) higher than Rosstat does. Oftentimes it is hard to assess the level of innovation activity in Russia due to the fact that they never reflect in analysis the level of output's novelty. This results in the erroneous view that innovation activity by particular enterprises, as opposed across an entire RIC as a whole, is a sufficient indicator of high levels of engagement of business entities in innovation processes.

Table 2. An Assessment of the Level of Innovation Activity in the Russian Federation Based on the Number of Innovation-Focused Companies and Indicators of Production of Innovative Output

\begin{tabular}{|c|c|c|c|c|}
\hline & Area of activity & \multicolumn{2}{|c|}{$\begin{array}{l}\text { Volume of innovative output with 'of own } \\
\text { production' status, trillion rubles }\end{array}$} & $\begin{array}{c}\begin{array}{c}\text { Number of companies, } \\
\text { thousand units }\end{array} \\
2016\end{array}$ \\
\hline \multirow{2}{*}{$\begin{array}{l}\text { Russian Federal State } \\
\text { Statistics Service }\end{array}$} & High-tech production operations & 2.048 & 2.248 & 1.32 \\
\hline & $\begin{array}{l}\text { Science-driven production } \\
\text { operations }\end{array}$ & 8.644 & 9.382 & 94.32 \\
\hline
\end{tabular}

Source: Compiled by authors

When it comes to percentage-based relationships, more specifically the relative share of enterprises engaged in technological innovation (R\&D) in the nation's total number of enterprises, they accounted for 7.3\% (2016), based on information from Rosstat. Here the way was led by the Central Federal District (nearly 9\%), with the rear brought up by the North Caucasian Federal District (just 2.6\%). A major negative trend is the steady decline in the relative share of innovation-focused enterprises, which started back in 2011 (Figure 1). 
As at January 1, 2017, innovative products turned, works carried out, and services provided accounted for around $12 \%$ of the nation's combined total. Here the way was led by the Central Federal District (nearly 15\%), with the rear brought up by the Far Eastern Federal District (around 1.5\%).

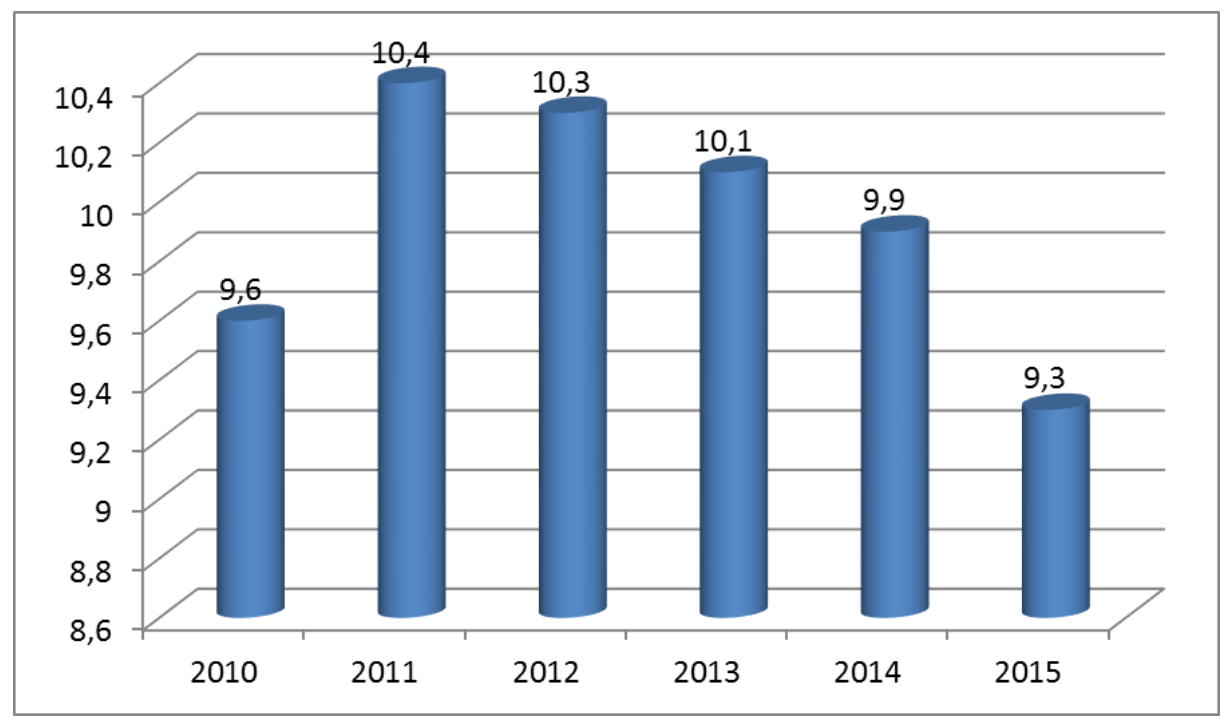

Fig.1. Dynamics of the relative share of innovation-focused enterprises in the Russian Federation

Source: Rosstat data (n.d.)

The share of all expenditure incurred in developing technological innovations relative to the overall volume of all goods produced, works carried out, and services provided as at January 1, 2017 was $2.5 \%$ across Russia as a whole. Leading and trailing positions were distributed similar to the regions' positions based on the share of innovation-focused enterprises. As at January 1, 2017, the volume of internal expenditure on the conduct of research and innovation activities was about 1.1\% relative to total GDP. It should also be noted that in Russia's budgets for the period 2016-2017 the share of expenditure on implementing civil science activities declined steadily (a decline of $14 \%$ in 2016).

Based on data from the Industrial Research Institute, in 2016 nearly $60 \%$ of all expenditure on R\&D was accounted for by the US, Japan, China, and Germany, with Russia's relative share coming in at just $2.6 \%$. A key negative factor is the lack of interest on the part of businesses in potentially taking part in funding support for the R\&D sphere. As evidenced from the National Report on Issues of Innovation in Russia, the nation lags significantly behind other countries in funding support for R\&D - and that is considering the input of even the nation's largest enterprises within RIC's. Russian enterprises operating within the nation's aviation and space industries, oil-and-gas sector, and automotive industry currently spend 2-3 times less than their counterparts in the leading countries of the world. Consequently, currently there is not a single Russian enterprise and not a single Russian RIC that is ranked among the best globally in expenditure on research and development, which reduces significantly the potential for the export of high-tech goods from Russia.

During the period 2016-2017, high-tech exports from Russia totaled around \$18-19 billion. In 2016, the figure was $\$ 18.3$ billion, with $63 \%$ of that accounted for by military-use products. Russia's key partners in that area include Algeria, Egypt, China, India, Kazakhstan, Belarus, and Iran. High-tech and intellectual goods and services accounted for around $30 \%$ of the nation's total exports of goods and services. This normally includes the following goods and services: goods and services related to space transportation, payments for the use of products of intellectual activity, computer, information, and telecommunications goods and services, services related to 


\section{ENTREPRENEURSHIP AND SUSTAINABILITY ISSUES}

ISSN 2345-0282 (online) http://jssidoi.org/jesi/

2019 Volume 6 Number 4 (June)

http://doi.org/10.9770/jesi.2019.6.4(24)

research and development, services related to consulting on issues of management, goods and services related to architecture, services related to product maintenance and repair, and various engineering services. Note that the greatest levels of revenue from the export of high-tech and intellectual goods and services in Russia were registered in 2013 ( $\$ 19.9$ billion). 2014 saw the emergence of a trend toward declines in the above exports, which had to do with sanctions pressure on Russia. In 2016, the nation's turnover in the area was $\$ 14.9$ billion. Figure 2 illustrates the structure of Russia's present-day export of high-tech and intellectual goods and services (Russia's Balance of Payments for 2016, n.d.).

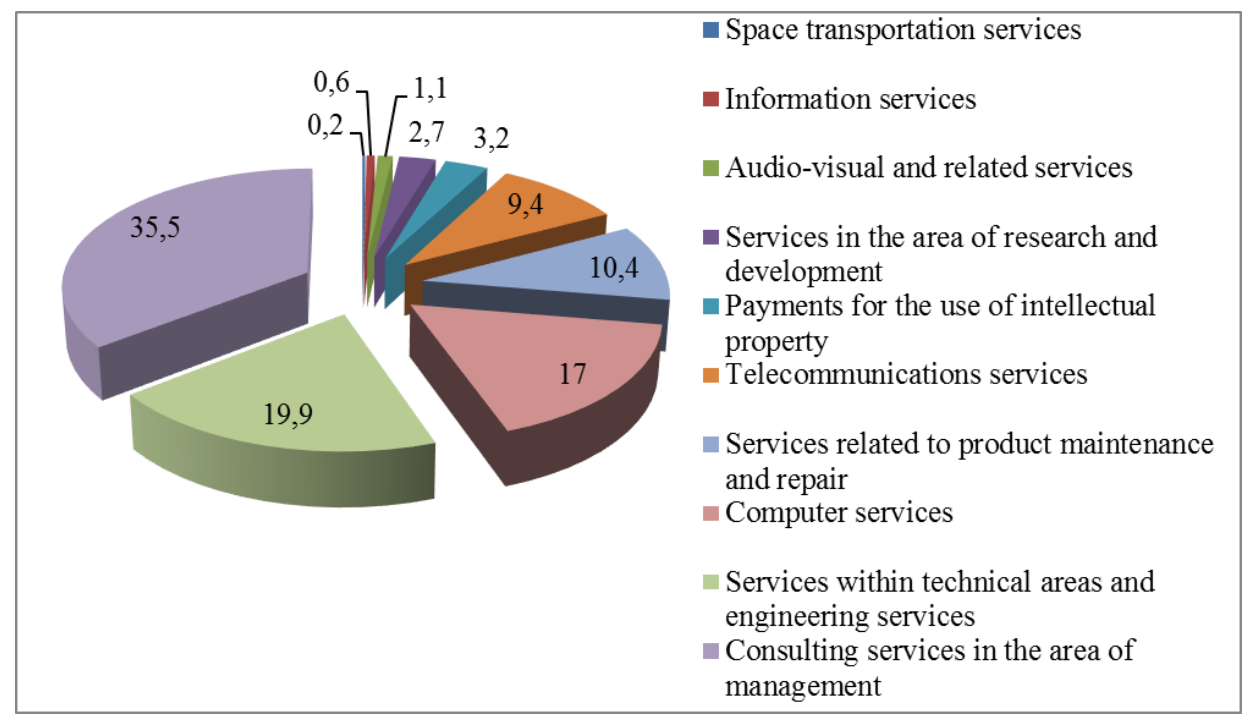

Fig. 2. Structure of the export of high-tech and intellectual goods and services from the Russian Federation in 2016.

Source: Compiled by Authors

Operations on the import of technology were, above all, dominated by engineering services (around 50\%). A high relative share was also exhibited by deals related to the acquisition of rights to trademarks and means of individualization (around 20\%). The share of know how in the nation's total imports was much greater than that in its total exports (around 5.7\% versus 1.3\%) (Likhachev, 2017). Note that Russia's export-import balance on innovative products and technologies is characterized by negative dynamics throughout the period under analysis. For instance, in 2016 the balance reached its worst level $--\$ 1,222$ billion, which means there is a need to take urgent measures to properly organize innovation activity in Russian industry both nationally and regionally.

It will also be worth devoting some attention to the sector in the innovations market which is concerned with products of intellectual activity. Note that, based on data from Clarivate Analytics, in 2016 Russian scientists published about 50,000 works. All in all, publications by Russian scientists accounted for $2.12 \%$ of total world publications (with Russia ranking 15th globally in publication activity level).

There is a key trend that may be illustrated by the fact that in 2016 out of 230,000 in-effect invention patents Russia's RICs made use of just 15,000 patents (around 7\%). A similar situation was observed in relation to all other products of intellectual activity as well: out of 53,000 in-effect patents for utility models the nation's RICs utilized just about 5,800 (around 11\%), while out of 30,500 patents for industrial designs only 1,800 were implemented by RIC enterprises (around 5.8\%). All this substantiates the fact that, while processes related to making use of products of intellectual activity are well-organized in Russia, processes related to commercializing them in RIC's may still require additional serious work. It should also be noted that oftentimes it happens that applications associated with obtaining a patent for an invention do not meet the criteria for RICs with respect to 


\section{ENTREPRENEURSHIP AND SUSTAINABILITY ISSUES}

ISSN 2345-0282 (online) http://jssidoi.org/jesi/

2019 Volume 6 Number 4 (June)

http://doi.org/10.9770/jesi.2019.6.4(24)

patentability (with around $20 \%$ of all decisions on granting a patent based on verdicts by industrial clients ending up negative).

\section{Discussion}

The above is testimony to the significance of putting together a proper model for managing the innovation-driven development of the nation's RICs, which would enable the rational and adaptive influence of participants in the innovations market on enterprises operating within the complex. In particular, within the setting of the federal segment the effect of the innovations market on RICs is reflected in the formation of a system of national needs for new types of innovative products, which is determining the nature of future economic activity in RICs in the context of federal special-purpose programs to be implemented. Also, within the setting of the federal segment of the innovations market there can be established civilized rules and conditions regarding the development, implementation, and rational use of products of innovation activity by business entities that form part of or are partners to RICs (Lvov \& Sorokin, 2005).

Within the setting of the sectoral segment, the effect of the innovations market on RICs is manifested in the formation and development of key institutional components which help ensure effective innovation activity at the sectoral and intersectoral levels of interaction between RIC and its partners. Also, within the setting of the sectoral segment of the innovations market there can be ensured crucial information and consulting cooperation between RIC and its partners on issues related to obtaining and putting to rational use innovative technologies and knowledge from participants in the sector with a view to boosting RIC's innovation potential and competitiveness (Kleiner, 2002). Finally, within the setting of the sectoral segment the effect of the innovations market on RICs is associated with that at this level of organizing innovation activity in the national economy there takes place the fine-tuning of relevant priorities and areas for the operation of sectors within the nation's industry and services sphere, which helps RICs distribute their resources in the right and judicious way across various programs and projects on innovation-driven development based on the criterion of boosts in the added value of innovative products turned out.

Within the setting of the regional segment, the effect of the innovations market on RIC is reflected in ensuring the conditions for the formation and timely manifestation of RIC's demand for R\&D products by participants in the innovations market, which helps model in the right way the system of funding and insuring the risks of programs and projects on RIC's innovation-driven development. Also, within the setting of the regional segment the effect of the innovations market on RIC helps strengthen relevant interrelationships and improve the effectiveness of interaction between RIC and its partners on R\&D, which may result in well-balanced cycles for creating innovative products (Iasin, 2009).

Within the setting of the corporate and intra-firm segments, the effect of the innovations market on RIC is manifested in that objects and subjects of the innovations market can accumulate best practices from various nations around the world in the area of organizing and managing innovation activity within RICs, with those best practices becoming accessible, through constructing experience curves and exchanging knowledge, for particular enterprises within RIC to enable them to effectively implement relevant programs and projects on innovationdriven development. Also, the effect of the innovations market on RIC within the setting of the corporate and intra-firm segments is reflected in the expansion of the conditions and potential for implementing a rational exchange of resources among participants in innovation activity, as well as the creation of an effective culture and a favorable innovation environment, which should stimulate inventor proaction and personnel creativity in the RIC. 
A proper insight into these aspects of influence helps establish the structure and key components of a model for managing the innovation-driven development of RIC in a climate of interaction with the innovations market (Figure 3).

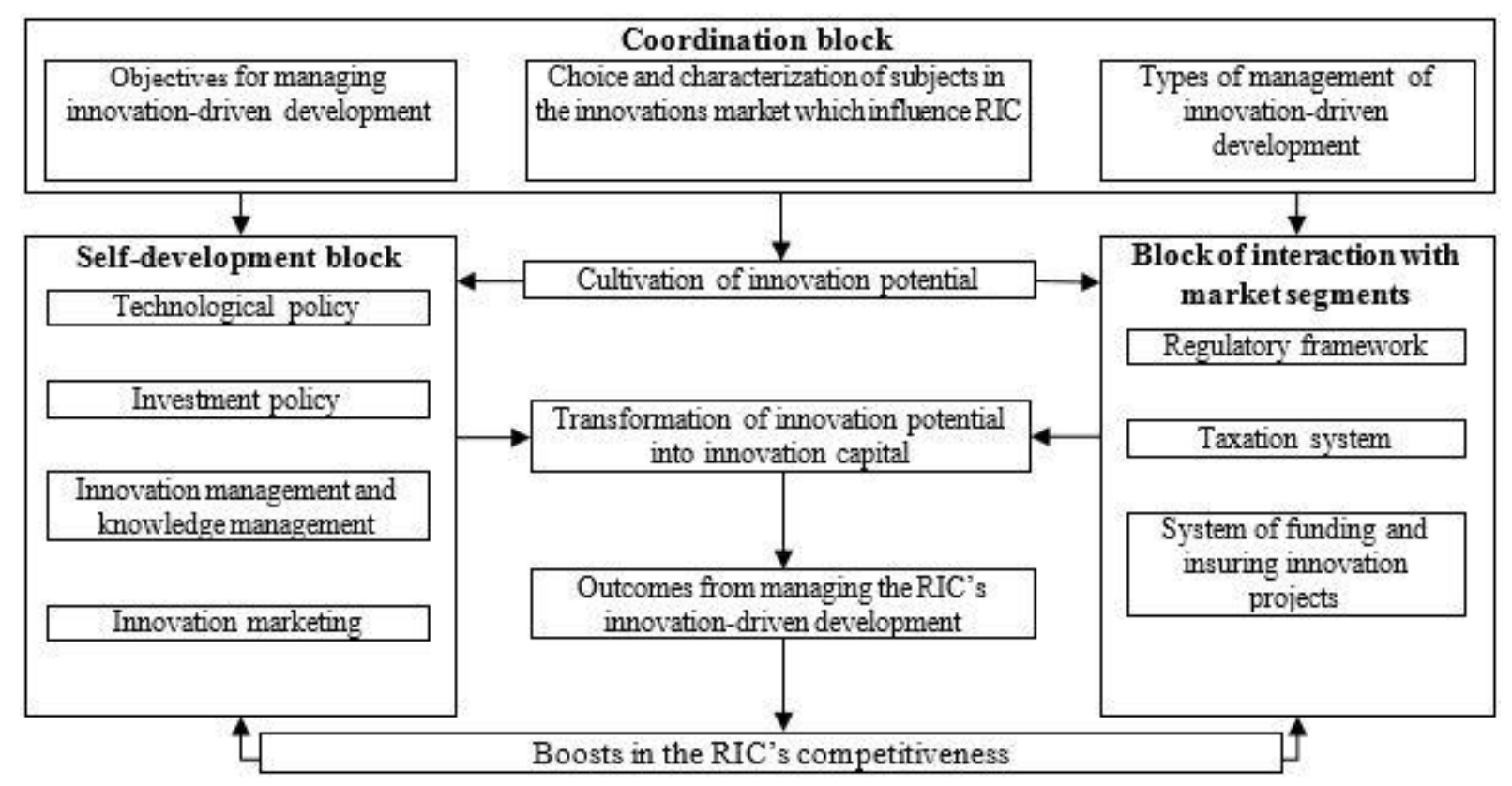

Fig. 3. Key components of a model for managing the innovation-driven development of RIC.

\section{Source: Compiled by Authors}

The key components in processes of innovation-driven development in RICs in a climate of interaction with the innovations market are the coordination block, the self-development block, and the block of rational interactions with segments within the innovations market, which help tie the nature of relationships within RIC to factors of the external and internal environment in the context of innovation activity and which help orient innovation processes toward the achievement of the maximum effect from interactions between the RIC and objects and subjects within the innovations market.

The coordination block determines relevant objectives for and corresponding types of management of innovationdriven development within RIC in accordance with the intensity of interaction between the RIC and various subjects in the innovations market. The relevance of the topic of managing innovation-driven development within RIC is associated with the need to combine services of industrial production and intensive innovation activity by business entities within the complex for the purpose of resolving a wide spectrum of organizational and managerial issues by way of ensuring the differentiation of the qualitative characteristics of innovation and production processes, as well as existing approaches to the effective management of these processes (Berg, 2000).

This approach to marking out a set of key components of management of innovation-driven development within RIC in a climate of interaction with the innovations market is associated with the centralization of the conduct of a set of basic research studies, as well as with the augmentation of processes of decentralization of innovation activities and ongoing improvements in innovative products and services from participants in the innovations market. What is actually manifesting itself here is the key principle of building the concept of managing innovation-driven development within RIC - the principle associated with the separation of strategies for innovation-driven development from tactics for the conduct of innovation activities (Milner, 2010). 


\section{ENTREPRENEURSHIP AND SUSTAINABILITY ISSUES}

ISSN 2345-0282 (online) http://jssidoi.org/jesi/

2019 Volume 6 Number 4 (June)

http://doi.org/10.9770/jesi.2019.6.4(24)

Below is an outline of the key subjects in the innovations market, based on the above-examined segments, which influence activity within RIC the most. The subjects in the federal segments of the innovations market which influence activity within RIC the most include federal research universities and state-run research centers. Federal research universities make it possible to implement the above-mentioned trend of decentralized innovation activities, which serves today as a basis for the diversification of innovative activity within RIC. Also, federal research universities can have a major effect on intellectual potential in RIC via the preparation of highly skilled and competent specialists who possess both basic and applied skills in organizing innovation and managerial business processes (Sapir \& Blinova, 2009).

The key subjects in the sectoral segment of the innovations market which influence activity in RIC the most include technology parks and business incubators. The effect of technology parks on RIC is associated with the conduct of R\&D activities and creation of trial designs of innovative products in them, which potentially may be of interest to enterprises within the RIC in terms of brand portfolio adaptation. It should also be taken into account that modern technology parks possess vast distributed bases of innovative resources which could be integrated into RIC's well-balanced innovation infrastructure, which may have a tangible effect in terms of transforming relevant priorities in organizing innovation processes in the RIC (Shevtsov, 2011).

The key subjects in the regional segment of the innovations market which influence activity in the RIC the most include regional innovation-technological centers, as well as regional centers for technology transfer. Regional innovation-technological centers can influence the prospects for innovation-driven development in RIC in the sense that they can take on the organization of the region's functional fairs for innovative products from economic entities within the RIC, which helps foster a sustainable and high demand for innovative solutions in the RIC (Akat'ev et al., 2009). Also, regional innovation-technological centers are oriented toward the organization of work dealing with the integration of the RIC's technological and economic sectors into the national and world innovation activity systems, which finds reflection in consulting for the RIC on issues related to deploying production operations in a region that have a focus on innovation, as well on issues related to support (participation of strategic partners) for research work in the RIC.

The key subjects in the corporate segment of the innovations market which influence activity in RIC the most include engineering establishments and agencies concerned with examination of innovation and investment projects. These subjects of the corporate segment facilitate better rationalization of prospective innovation activity organized in the RIC and help model innovation processes with enhanced characteristics in terms of resource intensity, infrastructural intensity, and efficient implementation.

Lastly, the key subjects of the intra-firm segment of the innovations market which influence activity in RIC the most include information networks and systems for transfer of knowledge among the personnel of business entities within the RIC. These subjects of the intra-firm segment help the RIC boost the effectiveness and promptness of managerial decision making. In other words, these subjects influence the efficiency of processes related to enhancing and expanding the potential for rational use of the system of managing innovation activity in the RIC.

Below is an itemized account of the effect of subjects of the various segments within the innovations market on activity and the prospects for managing innovation-driven development in RIC based on a set of relevant methods and mechanisms for ensuring the subjects' influence on the organization of innovation processes in the RIC.

Subjects of the federal segment within the innovations market influence RIC via: 


\section{ENTREPRENEURSHIP AND SUSTAINABILITY ISSUES}

ISSN 2345-0282 (online) http://jssidoi.org/jesi/

2019 Volume 6 Number 4 (June)

http://doi.org/10.9770/jesi.2019.6.4(24)

- $\quad$ the following methods: provision of support for strategic priorities for innovation activity; cultivation of international cooperation; creation of a favorable investment climate; protection of industrial products of intellectual activity;

- $\quad$ the following mechanisms: budgetary funding and lending; public-private partnerships; materialization of the outcomes from implementing scientific-technical policy.

Subjects of the sectoral segment within the innovations market influence RIC via:

- $\quad$ the following methods: facilitation of modernization; facilitation of competition in the innovation sphere; development of leasing of high-tech products; protection of the rights to own, use, and dispose of the results of innovation activity;

- $\quad$ the following mechanisms: coordination of economic interests; enhancement of economic interestedness; pricing stimulation (setting target prices and establishing concessionary prices); depreciation incentives.

Subjects of the regional segment within the innovations market influence RIC via:

- the following methods: development of the supply of innovations; expansion of the demand for innovations; development of small innovation-focused entrepreneurship; ensuring employment in the innovation sphere; protection of the rights and interests of business entities that are partners to the RIC on innovation activity; ensuring sustainable economic growth;

- $\quad$ the following mechanisms: market promotion; market expectations; shaping demand preferences; regional management (ensuring the link between innovations and regional priorities, adapting regional legislation, and developing regional innovation and structural policies).

Subjects of the corporate segment of the innovations market influence RIC via:

- the following methods: development of innovation infrastructure and improvement of the level of infrastructural intensity of innovations; development of integration processes; investing in innovations and boosting their effectiveness; development of contractual relationships; creation of coordination centers for innovation activity;

- $\quad$ the following mechanisms: adaptive management; creation of adaptive systems; infrastructural support; provision of scientific-methodological support (regulation of the organizational-legal characteristics of business activity; selection and implementation of various areas of planning, forecasting, and control over the outcomes of developing and implementing innovations; ensuring a rational exchange of resources).

Subjects of the intra-firm segment of the innovations market influence the RIC via:

- $\quad$ the following methods: ensuring a moral and material remuneration for authors of innovative solutions; creation of a competence enhancement system; creation of innovation-oriented project structures; development of a set of organizational and economic tools related to decision making;

- the following mechanisms: fostering an innovation-focused culture; development of a system of communicative interactions among participants in innovation processes; appraising employee performance; creation of a mentorship system; project management. 


\section{ENTREPRENEURSHIP AND SUSTAINABILITY ISSUES}

ISSN 2345-0282 (online) http://jssidoi.org/jesi/

2019 Volume 6 Number 4 (June)

http://doi.org/10.9770/jesi.2019.6.4(24)

\section{Conclusions}

The choice of specific methods and mechanisms for ensuring influence on RICs on the part of entities in segments within the innovations market must, above all, be based on the advisability of ensuring the intensive assimilation of the results of innovation activity among all RIC partners. In practice, a model for managing innovation-driven development within RIC must make it possible to ensure the priority of innovative activity as a key form of economic activity within the RIC, which, in turn, should help to radically change the nature of innovation activity within the RIC in the direction of ensuring economic growth, speeding up scientific-technical progress, and boosting the competitiveness of innovative products and services within the RIC. As a result, innovation activity within the RIC will develop mainly within the frame of areas conducive to boosts in the level of infrastructural development within the RIC and to improvements in the quality of work and in the level of labor productivity within regions' RIC. This will help reduce the degree to which domestic RICs are lagging behind similar industrial establishments in other countries.

\section{References:}

Akat`ev, V. P.; Alekseeva, M. B.; Savel’eva, S. B.; Koz`menko, S. Yu.; Bogachev, V. F.; Petko, O. V. 2009. Formirovanie promyshlennykh klasterov $v$ kontseptsii innovatsionnogo razvitiya regiona: Monografiya [The formation of industrial clusters and the concept of innovation-driven development in a region: A monograph]. Saint Petersburg, Russia: INFO-DA.

Aniskin, Iu. P.; Bulkanov, P. A.; Enikeeva, S. A.; Mitrokhin, D. I.; Nechepurenko, M. N. 2009. Upravlenie korporativnymi izmeneniyami po kriteriyu ustoichivosti [Managing corporate changes based on the sustainability criterion]. Moscow, Russia: Omega-L.

Berg, D. B. 2000. Evolyutsionnye modeli rosta $\mathrm{v}$ usloviyakh ogranichennykh resursov [Evolutionary models of growth in a climate of scarce resources]. In L. I. Abalkin (Ed.), Evolyutsionnaya ekonomika i meinstrim (Doklady i vystupleniya uchastnikov mezhdunarodnogo simpoziuma, g. Pushchino, 29 maya 1 iyunya 1998 g.) [An evolutionary economy and the mainstream (Presentations and speeches by participants in an international sympozium, Pushchino, May 29 - June 1, 1998)]. Moscow, Russia: Nauka.

Goncharenko, O.; Tohochynskyi, O.; Sirenko, K.; Chebonenko, S.; Tretiak, H. 2019. Innovative performance as precondition of sustainable and secure development, Journal of Security and Sustainability Issues 8(3): 531-544. https://doi.org/10.9770/jssi.2019.8.3(19)

Iasin, E. G. 2009. Modernizatsiya Rossii [Modernization of Russia]. Moscow, Russia: GU VShE.

Ignatavičius, R.; Tvaronavičienè, M.; Piccinetti, L. 2015. Sustainable development through technology transfer networks: case of Lithuania, Journal of Security and Sustainability Issues 4(3): 261-267. http://dx.doi.org/10.9770/jssi.2015.4.3(6) SCOPUS

Kleiner, G. B. 2002. Strategiya razvitiya predprinimatel'stva v real'nom sektore ekonomiki [Strategy for fostering entrepreneurship in the real sector of the economy]. Moscow, Russia: Nauka.

Likhachev, V. A. 2017. International technology transfer: main trends and Russia's position. Rossiyskiy Vneshneekonomicheskiy Vestnik, 10: $29-43$.

Lvov, D. S.; Sorokin, D. E. 2005. Rossiya v globaliziruyushchemsya mire: Strategiya konkurentosposobnosti [Russia in a globalizing world: Strategy for competitiveness]. Moscow, Russia: Nauka.

Milner, B. Z. 2010. Innovatsionnoe razvitie: Ekonomika, intellektual'nye resursy, upravlenie znaniyami: Monografiya [Innovation-driven development: Economics, intellectual resources, knowledge management: A monograph]. Moscow, Russia: INFRA-M.

Monni, S.; Palumbo, F.; Tvaronavičienè, M. 2017. Cluster performance: an attempt to evaluate the Lithuanian case, Entrepreneurship and Sustainability Issues 5(1): 43-57. http://doi.org/10.9770/jesi.2017.5.1(4)

Petrenko, Y.; Vechkinzova, E.; Antonov, V. 2019. Transition from the industrial clusters to the smart specialization of the regions in Kazakhstan, Insights into Regional Development 1(2): 118-128. https://doi.org/10.9770/ird.2019.1.2(3) 


\section{ENTREPRENEURSHIP AND SUSTAINABILITY ISSUES}

ISSN 2345-0282 (online) http://jssidoi.org/jesi/

2019 Volume 6 Number 4 (June)

http://doi.org/10.9770/jesi.2019.6.4(24)

Platezhnyi balans Rossiiskoi Federatsii za 2016 g. [Russia's balance of payments for 2016]. n.d. Retrieved from https://www.cbr.ru/vfs/statistics/credit_statistics/bop/bop_np-mc_2016.xlsx

Popkov, D. V.; Kotsiubinskii, V. A. 2017. Proizvodstvo vysokotekhnologichnoi produktsii grazhdanskogo naznacheniya v OPK Rossii do 2030 g. [Production of high-tech civil use output within Russia's military-industrial complex through to 2030]. Innovatsii, 8, 10-16.

Razminienè, K.; Tvaronavičienè, M. 2017. Economic globalization and its impacts on clustering, Terra Economicus, 15 (2): $109-121$ http://doi.org/10.23683/2073-6606-2017-15-2-109-121clustering.html

Sapir, E. V.; Blinova, T. S. 2009. Innovatsionnoe razvitie ekonomiki: Sushchnost', strategii, izmerenie: Monografiya [Innovation-driven development of the economy: Essence, strategy, measurement: A monograph]. Yaroslavl, Russia: Yaroslavskii Gosudarstvennyi Universitet.

Shevtsov, P. A. 2011. Chelovecheskii potentsial kak osnovnoi faktor innovatsionnogo razvitiya ekonomiki (statisticheskii aspect): Monografiya [Human potential as a key factor for the innovation-driven development of the economy (The statistical aspect): A monograph]. Moscow, Russia: Izdatel'stvo RGTEU.

Tvaronavičienè, M.; Razminienė K. 2017. Towards competitive regional development through clusters: approaches to their performance evaluation, Journal of Competitiveness, 9(4): 133 - 147, https://doi.org/10.7441/joc.2017.04.09

Tvaronavičienè, M. 2017. Clusters, innovations and energy efficiency: if relantionship could be traced, Marketing and Management of Innovations 2: 382 - 391 http://doi.org/10.21272/mmi.2017.2-35

Tvaronavičienė, M.; Černevičiūtè, J. 2015. Technology transfer phenomenon and its impact on sustainable development, Journal of Security and Sustainability Issues 5(1): 87-97. http://dx.doi.org/10.9770/jssi.2015.5.1(7)

Valter, N.; Androniceanu, A.; Dragulanescu, I.V.; Duca, M. Agile management based on modularization of products and processes, Proceedings of BASIQ International Conference - New Trends in Sustainable Business and Consumption, 2-3 June, 2016, Konstanz, Germany, Book series: Proceedings of BASIQ, pp: 310-318, Edited by: Rodica Pamfilie, Vasile Dinu, Laurențiu Tăchiciu, Doru Pleșea, Cristinel Vasiliu; ISSN 2457-483X.

Valery Vasilyevich BEZPALOV

ORCID ID: 0000-0002-4017-1328

Dmitry Valerievich FEDYUNIN

ORCID ID: 0000-0002-8526-3322

Natalya Anatolievna SOLOPOVA

ORCID ID: 0000-0003-2034-4321

Svetlana Alekseevna AVTONOMOVA

ORCID ID: 0000-0002-2468-5871

Sergey Alexandrovich LOCHAN

ORCID ID: 0000-0001-8704-7538 
ENTREPRENEURSHIP AND SUSTAINABILITY ISSUES

ISSN 2345-0282 (online) http://jssidoi.org/jesi/

2019 Volume 6 Number 4 (June)

http://doi.org/10.9770/jesi.2019.6.4(24)

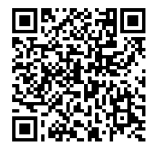

Register for an ORCID ID:

https://orcid.org/register

Copyright (C) 2019 by author(s) and VsI Entrepreneurship and Sustainability Center

This work is licensed under the Creative Commons Attribution International License (CC BY).

http://creativecommons.org/licenses/by/4.0/

(c) (i) Open Access 